DOI https://doi.org/10.18551/rjoas.2020-10.06

\title{
THE EFFECT OF TRUST-WORTHINESS, EXPERTNESS, SIMILARITY, AND ATTRACTIVENESS ON BRAND ATTITUDE AND ATTITUDE TOWARDS ADVERTISEMENTS AS MEDIATION VARIABLES IN BRAND X
}

\author{
Sulivyo Lod ${ }^{\star}$ \\ Sekolah Tinggi Ilmu Ekonomi Ppi, Indonesia \\ Handra Tessa \\ Multimedia Nusantara University, Indonesia \\ *E-mail: sulivyo.lod@stieppi.ac.id
}

\begin{abstract}
This study was designed to test empirical truths between two or more research variables that have been formulated in the hypothesis. The research variables used were expertness, trustworthiness, similarity, attractiveness, attitude to advertisement, and brand attitude. Exogenous variables in this study are expertness, trustworthiness, similarity, and attractiveness. Endogenous variables in this study are attitude to advertisement, and brand attitude. The results of the study concluded that only hypothesis 2 was not significant. There was no effect of trustworthiness on attitude to advertisement. Furthermore, Brand X should choose attractive celebrity endorsers in order to increase attitude towards advertisements, affecting brand attitude. Attractive celebrity endorsers are able to increase brand attention when it comes to physical appearance. In addition, further research can add other variables to determine the effect on brand attitude. Increasing the sample size is also highly recommended.
\end{abstract}

\section{KEY WORDS}

Expertness, trustworthiness, similarity, attractiveness, advertisement, brand attitude.

The current business competition is getting tougher, in which companies those are unable to anticipate this competition will be eliminated. They will eventually collapse and be defeated by their competitors. The war of product advertising in various media is one of the real phenomena that we can witness. Advertising is currently a part of promotion that is considered an effective and powerful source of information, entertainment, and business communication media.

Companies use a variety of tactics to influence target consumers and achieve the targets set for advertising. The most common tactic is the use of an endorser. An endorser is a person who supports or demonstrates a product and acts as a source of information. $\mathrm{He} / \mathrm{she}$ is expected to increase the effectiveness of advertising. In this case, celebrities are most frequently involved in becoming endorsers since they can attract consumers' attention with advertising messages, increase positive evaluation, and ultimately influence purchase attitudes and intentions. However, they are not always considered convincing or trustworthy as endorsers. Thus, the use of ordinary people as endorsers (hereinafter referred to as peer endorsers) has gained popularity in consumer advertising as a way to increase advertising credibility.

Furthermore, peer endorsers are likely to be more effective for certain types of products as a source of messages considering that they have properties indicating credibility to an audience. Endorsers' credibility is considered important especially when the audience has little or no other information from the advertising message. Additionally, the endorser associated with claims can only be verified through the experience of using the product.

One of the methods for assessing the effectiveness of advertisements is by looking at brand attitude. Lydia (2012) affirmed that brand attitude is the overall evaluation of consumers towards a brand, while a good brand attitude is able to increase consumer buying 
interest. Therefore, an analysis of the factors influencing brand attitude is an important analysis.

According to Munnukka, Uusitalo and Toivonen (2016), The factors that influence brand attitude include trustworthiness, expertness, similarity, attractiveness, and attitude towards advertisements. Trustworthiness indicates the extent to which a source can provide impartial and honest information (Novi, 2013). Expertness refers to the perceived ability of the information conveyed by a valid message source (Novi, 2013). Similarity is the same perception of the source against the receiver (Munnukka, Uusitalo, and Toivonen, 2016). Attractiveness is elements in celebrities that include a number of celebrity characteristics and can be seen by the audience, such as physical attractiveness, intelligence, personality traits and lifestyle (Kirby and Dadang, 2017). Mackenzie and Lutz as cited in Wangsa and Ardani (2015) claimed that attitude towards advertisements is the tendency of consumers to respond in a way that is favorable or unfavorable, positive, or negative to the advertisement as a whole.

Moreover, recipient's perception of the source's credibility influences the effectiveness of the advertisement. Credibility is built on two dimensions: trustworthiness and expertness. Trustworthiness can be positively influenced if the audience benefits from a product or service recommendation. The expertness of an endorser is important for consumer perception. The effectiveness of endorsers in communicating their expertise is in the form of experience and satisfaction that they feel based on the use of the advertised product. The higher the perception similarity, the higher the attitude towards the advertisement. The more attractive the endorsers are, the higher the attitude towards the advertisement. The positive relationship between attitude towards an advertisement and brand attitude has been verified in a number of studies. This relationship is influenced by whether consumers focus on content (affective elements, identify and match with endorsers) or context (cognitive elements, products and attributes). Importantly, a consumer who is involved in the advertisement content will form an attitude towards the advertisement, which is expected to have an impact on brand attitude (Munnukka, Uusitalo, and Toivonen, 2016).

\section{THEORETICAL REVIEW}

Brand credibility can be defined as believability of the product and information embedded in the brand. It depends on the consumer's perception whether the brand has the ability and willingness to continue delivering what has been promised. The more credible the brand is, the more likely it is to be included in the consumer's preferred list of purchases (Said and Mirza, 2018).

Brand credibility refers to trust in product information in a brand. It is needed by consumers to understand that the brand has the ability (expertise) and willingness (trust) to continuously deliver what has been promised. According to them, indicators of Brand Credibility can be measured through five kinds of questions: (1) Promise, (2) Concept, (3) Experience, (4) Commitment, and (5) Trust (Said and Mirza, 2018).

Attitude is said to be the most specific and indispensable concept in contemporary society. It is also one of the most important concepts that marketers use to understand consumers. The attitude of consumers towards brands means studying the tendency of consumers to consistently evaluate the liked and disliked brands. Consequently, consumers evaluate a particular brand as a whole from the worst to the best. Attitude towards a brand is a person's expression in evaluating a brand. It is a combination of consumer knowledge about a brand in order to evaluate the brand to form a choice.

According to Shiffman and Kanuk as cited in Gilang (2016), there are several components in determining attitudes listed as follows.

The first component of the attitude model consists of a person's various cognitions, including knowledge and perceptions obtained based on a combination of direct experience with attitude objects and related information from various sources. This knowledge and perception generated usually takes the form of consumer belief that an object of attitude has certain characteristics and behaviors that will cause certain results. 
Emotions and feelings about a particular product or brand are affective components of a particular attitude. Researchers believe that these emotions and feelings are highly evaluative; including one's assessment of attitude objects directly and thoroughly.

Conation is the last component of the attitude model, which deals with the possibility or tendency that individuals will take special actions or behave in certain ways towards certain attitude objects. In marketing research, the conative component is usually treated as an expression of a consumer's intention to buy or reject a product.

Endorser is basically a person or figure involved in marketing communication to convey a message to consumers either directly or indirectly. A celebrity endorser is any individual who benefits public recognition and uses it on behalf of a good consumer to appear in an advertisement. Based on the meaning distribution model, celebrity endorser also provides meaning and positive images to advertisements as well as communicate them to the advertised products (Lialutfi and Lilik, 2014).

An endorser is an advertising supporter or known as an advertisement star. Meanwhile, a celebrity is a figure known for his/her achievements in different fields from the products supported. A celebrity is also seen as an individual admired by society and usually attractive that differentiates them from other individuals. A celebrity can be used as a fast 'figure' to represent a targeted market segment considering that the messages conveyed attractively usually receive greater attention. This message will also be easy to remember. An endorser is often referred to as direct sources; a speaker who delivers a message and or demonstrates a product or service (Said and Mirza, 2018).

In order to attract consumers' attention and create preference for brands, it is necessary for a company to have a creative way of delivering advertisements. One of the creative ways to promote a product in the form of advertisement is by utilizing celebrity endorsers. It does need several considerations, including the level of celebrity popularity, whether the chosen celebrity can represent the character of the product being advertised. The use of endorsers is expected to provide a positive association between the product and the endorser. The associative can simply appear in the form of a particular thought or image associated with a brand (Novi, 2013).

Besides, celebrities represent an ideal lifestyle. Some people, especially their fans or followers, are usually interested in imitating their lifestyle. Seeing the market behavior that wants to imitate the lifestyle of celebrities, marketers are willing to spend a significant amount of money to use celebrities in promoting their products or brands. As a result, the target market will see, hear or read and then react positively by associating the product or brand with the celebrity promoting it. In order to rejuvenate a weary product or brand, companies are frequently lured into engaging celebrities. This idea is due to the fact that celebrity prestige has the potential to elevate the image of a brand and product, especially if there is a close relationship between the celebrity and the product it supports (Novi, 2013).

The term celebrity itself refers to well-known individuals (actors, sportsmen, entertained and others) for their success and achievements in areas that are in accordance with the product supported in an advertisement. Endorsement is a channel of marketing communication in which celebrities act as representations of a particular brand and emphasize that the brand represented represents personality, popularity and status in society or expertise in a particular field. In the brand market with local, regional and international level, celebrity endorsements are believed to make a difference from one brand to another (Daniel, 2016).

Celebrity credibility has an important role in creating a good perception of the product or brand advertised and increasing sales. Endorser credibility is one of the factors considered by respondents to believe the truth of the message content conveyed by advertisers. The use of endorsers in advertising needs to be evaluated by four indicators: popularity (visibility), credibility (credibility), attractiveness (attraction) and strength to drive the target (power). One of these indicators, visibility, has a dimension of how far a celebrity's popularity is. In terms of effectiveness, visibility is of much use if the purpose of the communication is brand awareness. Through the brand awareness, people are expected to get to know the brand name and continue to remember it as they remember the endorser 
(Novi, 2013). According to Aria and Elvira (2015), endorser credibility is divided into 3 (three) dimensions forming celebrity credibility:

It includes a number of characteristics that can be seen by the audience in the endorser, such as intelligence, personality traits, lifestyle, athleticism, and so on.

Celebrities can be trusted and are thought to have insight into certain issues, such as brand reliability. Thus, they will be the most capable of convincing others to make a decision in making a purchase transaction.

Expertise refers to knowledge, experience, or skills owned by an endorser related to the topic of his/her advertisement. Celebrity expertise in providing contact person for the product being promoted is able to bring consumers to participate in the utilization of the company's products.

The effect of trustworthiness on attitude towards advertisements. The recipient's perception of the source's credibility influences the effectiveness of the advertisement. Credibility is built on two dimensions, trust and expertise. Trust refers to the honesty, sincerity and truthfulness of the source, or the recipient's perception of the probability that supports communicating the claim he thinks is most true. Trust can be influenced positively if the audience benefits from the product or service recommendation (Munnukka, Uusitalo and Toivonen, 2016).

The effect of expertness on attitude towards advertisements. Expertise refers to the perceived competence of a source to make a claim, such as an endorser's knowledge, experience, or skills. Previous research has shown that an endorser's actual skills matter to consumer perceptions. The effectiveness of endorsers in communicating their expertise is in the form of experience and satisfaction that they feel based on the use of the advertised product (Munnukka, Uusitalo and Toivonen, 2016).

The effect of similarity on attitude towards advertisements. The attractiveness of an endorser is related to the same perception of an audience. Advertisement for children's products will be more effective if the actors are a mother and a child because the product is related to the child and thus requires the perception of the mother and the child. The higher the perception similarity, the higher the attitude towards advertisements (Munnukka, Uusitalo and Toivonen, 2016).

The effect of attractiveness on attitude towards advertisements. The attractiveness of an endorser has been shown to positively affect the credibility of an advertisement only if the product is related to physical appearance. Therefore, cosmetic endorsers, especially celebrities, are considered attractive. The more attractive the endorser is, the higher the attitude towards advertisements (Munnukka, Uusitalo and Toivonen, 2016).

The effect of attitude towards advertisement on brand attitude. nA positive relationship between attitude towards advertisements and brand attitude has been verified in a number of studies. This relationship is influenced by whether consumers focus on content (affective elements, identify and match with endorsers) or context (cognitive elements, products, and attributes). Importantly, a consumer who is involved in the advertisement content will form an attitude towards the advertisement, which is expected to have an impact on brand attitude (Munnukka, Uusitalo and Toivonen, 2016).

\section{METHODS OF RESEARCH}

This study was designed to test the empirical truth between two or more research variables that have been formulated in the hypothesis. Research variables included expertness, trustworthiness, similarity, attractiveness, attitude towards advertisements, and brand attitude. Exogenous variables in this study were expertness, trustworthiness, similarity, and attractiveness. Endogenous variables in this study covered attitude towards advertisements, and brand attitude. Data were collected using questionnaires, which were then analyzed using partial least squares. 


\section{RESULTS AND DISCUSSION}

Validity Testing. Agus (2015) strongly advocated that corrected convergent validity test is declared valid if the loading factor value is greater or equal to 0.3. Meanwhile, Discriminant validity is seen from the AVE value and is declared valid if it is greater than or equal to 0.5 (Agus, 2015). The results of the convergent validity test can be seen in the following table:

Table 1 - Smartpls Output for Validity Testing

\begin{tabular}{|c|c|c|c|c|c|c|}
\hline & A & ATA & BA & $\mathrm{E}$ & $\mathrm{s}$ & $\mathrm{T}$ \\
\hline A1 & 0.981 & & & & & \\
\hline A2 & 0.967 & & & & & \\
\hline$A 3$ & 0.975 & & & & & \\
\hline A4 & 0.964 & & & & & \\
\hline ATA1 & & 0.987 & & & & \\
\hline ATA2 & & 0.988 & & & & \\
\hline ATA3 & & 0.981 & & & & \\
\hline ATA4 & & 0.988 & & & & \\
\hline BA1 & & & 0.950 & & & \\
\hline BA2 & & & 0.890 & & & \\
\hline $\mathrm{BA} 3$ & & & 0.913 & & & \\
\hline E1 & & & & 0.944 & & \\
\hline E2 & & & & 0.956 & & \\
\hline E3 & & & & 0.943 & & \\
\hline E4 & & & & 0.943 & & \\
\hline S1 & & & & & 0.988 & \\
\hline $\mathrm{S} 2$ & & & & & 0.985 & \\
\hline S3 & & & & & 0.984 & \\
\hline $\mathrm{T} 1$ & & & & & & 0.967 \\
\hline $\mathrm{T} 2$ & & & & & & 0.983 \\
\hline T3 & & & & & & 0.979 \\
\hline T4 & & & & & & 0.968 \\
\hline
\end{tabular}

Source: processed by the researchers.

Based on the data, statement items for attractiveness have the highest loading factor value of 0.981 and the lowest of 0.964 . Statement items for attitude towards advertisements have the highest loading factor value of 0.988 and the lowest of 0.981 . In addition, statement items for brand attitude have the highest loading factor value of 0.950 and the lowest of 0.890. Statement items for expertness have the highest loading factor value of 0.956 and the lowest of 0.943 . Besides, statement items for similarity have the highest loading factor value of 0.988 and the lowest of 0.984 . Statement items for trustworthiness have the highest loading factor value of 0.983 and the lowest of 0.968 . After being tested for convergent validity, then it was tested for discriminant validity by looking at the AVE value (Agus, 2015). The following is the Smartpls output:

Table 2 - Average Variance Extracted (AVE) and Cronbach's Alpha

\begin{tabular}{|l|r|r|r|r}
\hline & Cronbach's Alpha & rho_A & Composite Reliability & Average Variance Extracted (AVE) \\
\hline A & 0.980 & 0.981 & 0.985 & 0.944 \\
\hline ATA & 0.990 & 0.991 & 0.993 & 0.972 \\
\hline BA & 0.906 & 0.912 & 0.941 & 0.842 \\
\hline E & 0.961 & 0.961 & 0.972 & 0.896 \\
\hline S & 0.986 & 0.986 & 0.991 & 0.972 \\
\hline T & 0.982 & 0.983 & 0.987 & 0.949 \\
\hline
\end{tabular}

Source: processed by the researchers. 
Based on Table 2, the AVE value for each variable is greater than 0.5. Thus, all statement items are declared valid in a discriminant manner. Instrument reliability testing was carried out using Cronbach's Alpha analysis.

According to Malhotra (2004), Cronbach's Alpha is the average across the coefficients that may be the result of different ways of dividing the scale items. Referring to Table 2, Cronbach's Alpha value for each variable is greater than 0.7 . Therefore, it can be concluded that the statement items for each variable are reliable.

Hypothesis Testing. Following are the results of the SEM PLS analysis in the research analysis:

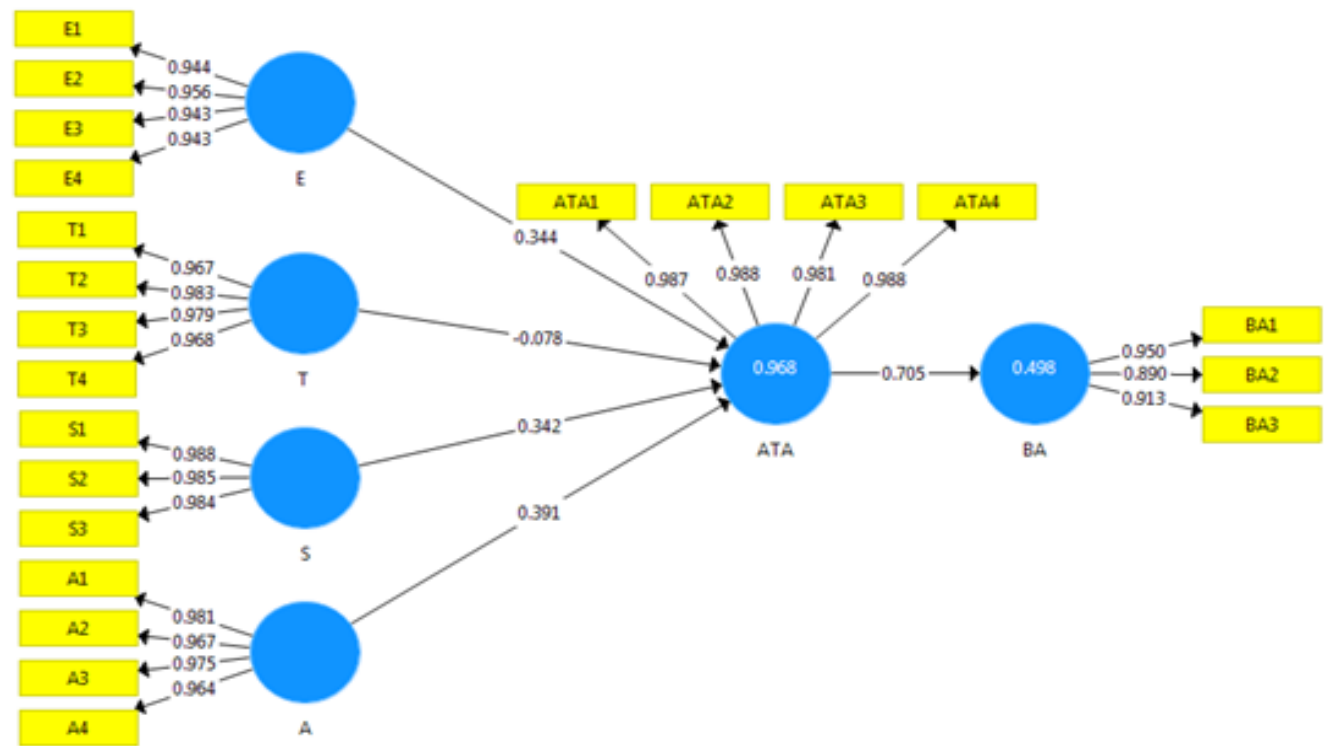

Figure 1 - SmartPLS Output

Table 3 - Summary of Hypothesis Testing

\begin{tabular}{|l|c|c|c|c|}
\hline \multicolumn{1}{|c|}{ Hypothesis } & $\begin{array}{c}\text { Original } \\
\text { Sample }\end{array}$ & $\begin{array}{c}\mathrm{T} \\
\text { Statistic }\end{array}$ & P Values & Model Evaluation \\
\hline Expertness - Attitude towards advertisements & 0.344 & 3.690 & 0.000 & Significant \\
\hline Trustworthiness - Attitude towards advertisements & -0.078 & 0.782 & 0.435 & Not Significant \\
\hline Similarity - Attitude towards advertisements & 0.342 & 2.943 & 0.003 & Significant \\
\hline Attractiveness - Attitude towards advertisements & 0.391 & 4.116 & 0.000 & Significant \\
\hline Attitude towards advertisements - Brand attitude & 0.705 & 9.199 & 0.000 & Significant \\
\hline
\end{tabular}

Source: processed by the researchers.

Based on Table 3, p-value for hypothesis 1 is $0.000<0.05$. It means that there is an effect of expertness on attitude towards advertisements. Moreover, $p$-value for hypothesis 2 is $0.435>0.05$, indicating that there is no effect of trustworthiness on attitude towards advertisements. Besides, $p$-value for hypothesis 3 is $0.003<0.05$, which means that there is an effect of similarity on attitude towards advertisements. Importantly, p-value for hypothesis 4 is $0.000<0.05$, meaning that there is an effect of attractiveness on attitude towards advertisements. Last but not least, p-value for hypothesis 5 is $0.000<0.05$, which indicates that there is an effect of attitude towards advertisements on brand attitude.

\section{DISCUSSION OF RESULTS}

There is an effect of expertness on attitude towards advertisements. It is in line with a research conducted by Munnukka, Uusitalo and Toivonen (2016). Expertise refers to the perceived competence of a source to make a claim, such as an endorser's knowledge, experience, or skills. Previous research has shown that an endorser's actual skills matter to 
consumer perceptions. The effectiveness of endorsers in communicating their expertise is in the form of experience and satisfaction that they feel based on the use of the advertised product.

There is no effect of trustworthiness on attitude towards advertisements. This result is inconsistent with a research of Munnukka, Uusitalo and Toivonen (2016). The recipient's perception of the source's credibility influences the effectiveness of the advertisement. Trust indicates honesty, sincerity and truthfulness of the source, or the recipient's perception of the probability that supports communicating the claim he thinks is most true. Trust can be influenced positively if the audience benefits from the product or service recommendation. However, respondents' knowledge of products can affect their knowledge of advertisement. Those who do not know about product advertisements think that trust in products only affects brand attitudes.

There is a similarity influence on attitude towards advertisements. The attractiveness of an endorser is related to the similarity of perception to an audience. It is in line with results of a research conducted by Munnukka, Uusitalo, and Toivonen (2016). Advertisement for children's products will be more effective if the actors are a mother and a child because the product is related to the child and thus requires the perception of the mother and the child. The higher the perception similarity, the higher the attitude towards advertisements

There is an effect of attractiveness on attitude towards advertisements. This is in accordance with a research by Munnukka, Uusitalo and Toivonen (2016). The attractiveness of an endorser has been shown to positively affect the credibility of an advertisement only if the product is related to physical appearance. Therefore, cosmetic endorsers, especially celebrities, are considered attractive. The more attractive the endorser is, the higher the attitude towards advertisement.

There is an effect of attitude towards advertisements on brand attitude. This is consistent with the research of Munnukka, Uusitalo and Toivonen (2016). The positive relationship between attitudes towards an advertisement and brand attitudes has been verified in a number of studies. This relationship is influenced by whether consumers focus on content (affective elements, identify and match with endorsers) or context (cognitive elements, products, and attributes). A consumer who is involved in the advertisement content will form an attitude towards the advertisement, which is expected to have an impact on brand attitude.

\section{CONCLUSION}

Based on the research results, there is only hypothesis 2 which is not significant; there is no influence of trustworthiness on attitude towards advertisements. Brand $X$ should choose expert celebrity endorsers in order to increase attitude towards advertisements and have an impact on brand attitude. Expert celebrity endorsers are able to communicate the use or performance results of a brand, which finally can support the brand attitude. Furthermore, Brand $X$ should choose attractive celebrity endorsers in order to increase attitude towards advertisements, affecting brand attitude. Attractive celebrity endorsers are able to increase brand attention when it comes to physical appearance. In addition, further research can add other variables to determine the effect on brand attitude. Increasing the sample size is also highly recommended.

\section{REFERENCES}

1. Agus, W. (2015). Analisis Statistika Multivariat Terapan. Yogyakarta: UPP STIM YKPN.

2. Alatas, S. L., \& Tabrani, M. (2018). Pengaruh Celebrity Endorser Terhadap Purchase Intention Melalui Brand Credibility. Jurnal Manajemen Inovasi, 9(1).

3. Dharma, K. N. A., \& Iskandar, D. (2017). Pengaruh Celebrity Endorser Jkt48 Terhadap Minat Beli Konsumen Im3 Play (studi Kasus Pada Pengunjung Teater Jkt48 Periode 21 Februari 2016). EProceedings of Management, 4(2).

4. Malhotra, N. K. (2004). Marketing Research - An Applied Orientation . New Jersey: Person Education. Inc. 
5. Mayangsari, L., \& Rudianto, Y. L. (2014). Pengaruh Dukungan Endorser and Brand Familiarity Terhadap Perception Of Purchase Risk and Dampaknya Pada Niat Beli Produk Brand Extension. Jurnal Manajemen Teori and Terapan| Journal of Theory and Applied Management, 7(2).

6. Munggaran, A. P., \& Azis, E. (2015). Pengaruh Endorser Credibility Terhadap Minat Beli Konsumen (studi Kasus Pada Distro Screamous). EProceedings of Management, 2(3).

7. Munnukka, J., Uusitalo, O., \& Toivonen, H. (2016). Credibility of a peer endorser and advertising effectiveness. Journal of Consumer Marketing.

8. Novi, R. P. (2013). Pengaruh Penggunaan Selebriti dalam Iklan terhadap Minat Beli Konsumen Pelembab Muka Pond's Di Kota Semarang. Jurnal Ekonomi, 3(1).

9. Setiono, L. (2013). Pengaruh variabel trust, perceived value, brand attitude and customer satisfaction terhadap customer loyalty pelanggan McDonalds Drive Thru di Surabaya [PhD Thesis]. Widya Mandala Catholic University.

10. Shiffman, L., \& Kanuk, L. (2010). Consumer behavior: Global edition. Pearson Higher Education. London.

11. Wangsa, G. C. U., \& Ardani, I. G. A. K. S. (2015). Peran Sikap pada Iklan dalam Memediasi Pengaruh Kredibilitas Al Ghazali sebagai Endorser terhadap Niat Beli (Studi pada Produk Men's Biore Cool Oil Clear di Kota Denpasar). E-Jurnal Manajemen Universitas Udayana, 4(3).

12. Wardhana, D. Y. (2016). Pengaruh Kredibilitas Endorser pada Niat Beli Konsumen and Tingkat Kepercayaan pada Iklan. KINERJA, 20. 